\title{
MENAPAKI KEMBALI SEJARAH DAN GERAKAN ISU ROMUSHA DI INDONESIA
}

\author{
Anugrah Saputra \\ Universitas Budi Luhur \\ email:putra_alegro@yahoo.com
}

Paper Accepted: 28 Juni 2018 Paper Reviewed: 7-15 Juli 2018 Paper Edited: 17-24 Juli 2018 Paper Approved: 25 Juli 2018

\begin{abstract}
The research discuss about forced labor practices in Indonesia under Japanese Military invation. The focus of this paper is to highlight how the idea of forced labor context, the mobilization process and to describing, also reveals preliminary findings on the ground in relation to Romusha's case study at village in Boyolali. In this papaer also will be presented how the future of that issues and humanitarian movement Romusha in Indonesia recently. I used literature and field studies by presenting some of the survivor (ex-romusha). The result of this study bring the conclusions of discussion and history alignment to the younger generation should be continue and so that we can moving into a better future.
\end{abstract}

Keywords: romusha in indonesia; japanese military invation

\section{PENDAHULUAN}

Periode Invasi Jepang 1942-1945 di Indonesia seolah memiliki dua sisi mata uang; sejarah masa kelam bangsa dan menguatnya rasa nasionalisme. Masa kelam tersebut terjadi karena eksploitasi di hampir seluruh lapisan masyarakat untuk kepentingan perang Asia Timur Raya, dan untuk ekspansi Militer Jepang.

Eksploitasi semakin menjadi karena kerjasama yang kuat antara Pemerintahan Militer Jepang dan kelompok nasionalis yang menyambut dan mengelukan-elukan kekuatan Jepang sebagai bangsa pembebas akibat frustasi dijajah Kolonial Belanda.

Pada 8 Maret 1942, hanya dalam tempo 8 hari Militer Kekaisaran Jepang berhasil menaklukkan Hindia Belanda secara de jure. Kesuksesan Militer Jepang menduduki wilayah Hindia Belanda akhirnya membuat pasukan Belanda dan sekutu hengkang tunggang langgang meninggalkan Hindia Belanda atau rela menjadi tawanan perang.

Rangkaian invasi panjang yang dilakukan oleh Militer Jepang dari tahun 1939 mencakup wilayah China (Peking dan Nanking) dan wilayah selatan (Korea, Indochina, Burma, Filipina, Hongkong, Malaya, Singapura, dan Hindia Belanda). Kepongahan supremasi militer bangsa eropa tumbang begitu saja karena agresifitas Militer Jepang membabat habis wilayah selatan untuk dikuasai. Panjangnya waktu kampanye militer secara besar-besaran tersebut amat menguras sumberdaya dan energi Militer Jepang sehingga membutuhkan wilayah taklukan sebagai basis sumber daya alam dan manusia.

\section{Perumusan Masalah}

Dalam penelitian ini, pokok permasalahan yang diangkat adalah bagaimana terbentuknya ide kerja paksa dan proses mobilisasi dalam praktik kerja paksa (romusha) tersebut?.

\section{METODE PENELITIAN}

Penelitian ini menggunakan metode kualitatif deskriptif dengan pendekatan studi pustaka. Menurut Nana Syaodih Sukmadinata (2011: 73), penelitian deskriptif kualitatif ditujukan untuk mendeskripsikan dan menggambarkan fenomena-fenomena yang ada, baik bersifat alamiah maupun rekayasa manusia, yang lebih memperhatikan mengenai karakteristik, kualitas, keterkaitan antar kegiatan. Studi pustaka dilakukan untuk mengumpulkan dan mengidentifikasi berbagai literatur terkait penelitian tersebut. 


\section{PEMBAHASAN}

\section{Ide Kerja Paksa Romusha}

Hengkangnya pemerintahan Kerajan Belanda membuat wilayah Hindia Belanda kosong pemerintahan. Karena luasnya wilayah Hindia Belanda yang diekspansi Jepang, maka untuk mengefektifkan wilayah pendudukan, administrasi pemerintahan dibagi ke dalam tiga daerah, yaitu:

1) Pemerintahan Militer Angkatan Darat (Tentara Rikigun Kedua Puluh Lima) untuk Sumatra, Berkedudukan di Bukittinggi;

2) Pemerintahan Militer Angkatan Darat (Tentara Rikigun Keenam Belas) untuk Jawa dan Madura, berkedudukan di Jakarta.

3) Pemerintah Militer Angkatan Laut (Kaigun Armada Selatan Kedua) untuk daerah yang meliputi Sulawesi, Kalimantan, Maluku, berkedudukan di Makassar.

Melalui pembagian wilayah kekuasaan tersebut diharapkan stabilitas dan kekacauan karena beralihnya pemerintahan dapat dicegah sedini mungkin. Oleh karena itu pada tanggal 20 Maret 1942 diumumkan Undang-undang No.3 yang melarang segala macam bentuk pertemuan, pergerakan, atau anjuran propaganda yang menyangkut hal-hal mengenai perturan dan susunan negara. (Herkusumo, A. Prasedyawati. 1982).

Undang-undang tersebut juga menjelaskan bahwa peraturan tersebut dibuat untuk sementara waktu, untuk mencegah timbulnya kekuatan politik di Indonesia, dan agar rakyat memikirkan sedalam-dalamnya bagaimana cara bekerja sama dengan pemerintahan pendudukan (Militer Jepang).

Pemulihan menjaga stabilitas peralihan kekuasaan dari Belanda ke militer Jepang ditandai dengan peraturan untuk yang bersifat "menjepangkan" Indonesia dan perubahan struktur pemerintahan. Pemeritahan Belanda dihapuskan yang kemudian digantikan dibentuknya pemerintahan militer yang bersifat sementara, dibentuknya Kantor Pemerintahan Militer Jawa (Jawa Gunseibu) yang berada langsung di bawah Kepala Staf Tentara Keenam Belas, sekaligus diangkat sebagai kepala pemerintahan.

Pemerintahan Militer ini memiliki delapan departemen sebagai penunjang jalannya pemerintahan. Departemen tersebut antara lain Departemen Urusan Umum (Somubu), Departemen Dalam Negeri (Naimbu),
Departemen Perekonomian (Sangyobu), Departemen Keuangan (Zaimubu), Departemen Kehakiman (Shihobu), Departemen Kepolisian (Keimubu), Departemen Lalu-Lintas (Kotsubu), dan Departemen Propaganda (Sendenbu) (Mr. A.A. Zorab, dikutip dalam Herkusumo, 1982: 10).

Pendudukan wilayah di Jawa juga dilakukan untuk pemerintahan setempat di Jawa dan Madura -kecuali DIY dan Surakarta - yang dibagi menjadi tujuh belas keresidenan (shu) yaitu Banten, Jakarta, Bogor, Priangan, Cirebon, Pekalongan, Semarang, Banyumas, Pati, Kedu, Surabaya, Bojonegoro, Madiun, Kediri, Malang, Besuki, dan Madura.

Di Pemerintahan Daerah sendiri di setiap tingkatan menggunakan nama Jepang, yaitu ken (kabupaten), gun (kewedanaan), son (kecamatan), dan $k u$ (desa). Di Sumatera dibagi menjadi shu, bunshu, gun, dan son. Pemerintahan Militer di Sumatera membagi sembilan shu, yaitu Sumatra Timur, Sumatra Barat, Riau, Jambi, Bengkulu, Palembang, Lampung, dan Bangka-Belitung. Untuk Pemerintahan Militer Angkatan Laut membentuk Minseifu (Kantor Pemerintahan Sipil), yakni Kalimantan, Sulawesi, Maluku, dan Sunda Kecil, yang dibagi lagi menjadi shu, ken, bunken, gun, dan son. Semua Jabatan dipegang oleh orang Jepang.

Pada masa ini golongan nasionalis yang kooperatif dengan Pemerintahan Militer Jepang membentuk usaha-usaha bersama dalam bentuk organisasi massa. Pihak Militer Jepang pun tidak mau ketinggalan untuk memanfaatkan gerakan itu untuk memobilisasi masa guna kepentingan dukungan kampanye militer di kawasan Asia-Pasifik untuk menaklukkan Tentara Sekutu. Terbentuklah Gerakan Tiga A dan Poetra (kemudian berganti menjadi Hokokai) sebagai wadah pemusatan konsentrasi massa (Ricklefes, M.C. 2005).

Melalui tokoh pengerak yang dikenal dengan empat serangkai, yaitu Ir. Soekarno, Mohammad Hatta, K.H. Mas Mansur, dan Ki Hadjar Dewantara, selain kelompok Nasionalis yang dinilai kooperatif oleh Militer Jepang, golongan Islam pun mendapat tempat dipanggung gerakan keagamaan sehingga organisasi seperti MIAI, Muhammadiyah, dan Nahdatul Ulama diijinkan berdiri kembali.

Sementara upaya stabilitas berlangsung di kawasan Hindia Belanda di luar sana, Tentara Jepang semakin merangsek di wilayah pulaupulau kecil di Laut Pasifik. Hal itu digunakan untuk merebut wilayah pendudukan guna membentengi gerak serangan Pasukan Amerika, Australia, dan Pasukan sekutu lainnya. 
Kekalahan telak armada Jepang terjadi di Coral Sea dan Midway menyebabkan banyak armada militer termasuk pasukan telah menjadi korban. Kegagalan tersebut membawa implikasi yang besar sehingga, praktis kekalahan Militer Jepang sudah semakin di depan mata.

Kondisi tersebut membuat sontak Parlemen di Jepang dan Pemerintahan Militer Jepang sehingga membuat keputusan untuk semakin meningkatkan eksploitasi sumber daya yang dimiliki Hindia Belanda, termasuk manusia sebagai alat perang. Untuk itu partisipasi politik yang melibatkan kelompok nasionalis kooperatif ke dalam sebuah Dewan Pertimbangan Pusat (Chuo Sangi-in) menjadi mutlak. Tokoh empat serangkai digandeng untuk memuluskan rencana ini, sehingga dibentuklah keanggotaa sebanyak 23 orang yang diangkat oleh Saiko Shikikan (Panglima Tertinggi Tentara Keenam Belas) melalui rekomendasi perwakilan di daerah-daerah.

Chou Sangi-in secara resmi bersidang pertama kali 16 - 20 Oktober 1943. Tujuan sidang ini dimaksudkan untuk semakin mempertegas bahwa rakyat Indonesia dapat bahu-membahu untuk mewujudkan kemenangan Kemaharajaan Kaisar Jepang (Tenno) di Asia Timur Raya. Akhir sidang tanggal 20 Oktober 1943 menghasilkan keputusan dengan arahan Saiko Shikikan melalui mediasi dengan Departemen Urusan Umum bahwa disepakati langkah-langkah yang dilakukan oleh pemerintahan di Indonesia:

1) Memperkuat dan melindungi para prajurit Peta dan Heiho;

2) Menggerakan Tenaga Kerja untuk keperluan masyarakat dan perang;

3) Meneguhkan susunan penghidupan masyarakat dalam masa perang;

4) Memperbanyak hasil bumi.

Pada butir kedua operasionalisasinya dibentuk pengorganisasian masa dengan membentuk Romusha (dalam bahasa propaganda ialah prajurit pekerja). Untuk mengorganisasi ini dibutuhkan perangkat lokal mulai shu (keresiden), ken (kabupaten), gun (kewedanaan), son (kecamatan), dan $k u$ (desa), menyusul dibentuknya Kumai (Koperasi), Tonarigumi (Rukun Tetangga) (Teliti Kurasawa dan Shiraishi. 1988).

Hal itu dilakukan untuk memobilisasi massa secara masal, sukarela, dan cepat. Karena masyarakat semi-feodal pada waktu itu amat takut dan tunduk oleh institusi pemerintah (seperti hubungan raja dan bawahan atau patron dan klien). Proses rekrutmen dilakukan dengan sistematik, karena melibatkan pemerinta setempat. Hal itu dilakukan dengan iming-iming sandang, papan, dan pangan yang layak serta merupakan bagian tudas dari masyarakat dese tempat mereka tinggal.

Proses rekrutmen tersebut memanfaatkan strutur sosial dan pemerintahan yang terbentuk, terutama sejak culturstelsel yang mengelompokan wilayah tradisional menjadi kesatuan administratif desa yang di dalamnya terdiri dari lapisan stratifikasi orang berdasarkan kedudukan dan status sosialnya.

Itulah sekelumit mengenai rencana awal eksploitasi manusia sebagai pekerja paksa dari mulai aturan sampai pada oprasionalisasi dilapangan yang langsung melibatkan tokoh nasional yang berpengaruh, perangkat pemerintahan, serta tokoh yang ada dipelosok wilayah desa (seperti, kiyai dan pemuka adat).

\section{Praktik Romusha Di Indonesia}

Romusha merupakan tenaga buruh kerja paksa yang direkrut berumur sekira 16-40 tahun, baik perempuan dan laki-laki. Praktik romusha ini dimobilisasi mengunakan struktur pemerintahan yang paling relatif dekat di level kecamatan (son), desa $(k u)$, dan rukun tetangga (Tonarigumi). Mereka bekerja untuk Militer Jepang melalui aparat pemerintahan lokal dengan instruksi bersifat sukarela dan memaksa. Setiap tiga wilayah yang dibagi tiga pemerintahan militer, memiliki dan mengorgaisasi pekrja sebagai romusha. Namun yang banyak dimobilisasi masal ialah orang yang berasal dari Pulau Jawa.

Pemobilisasian dilakukan untuk wilayah yang menurut Kepala Pemerintahan Jepang perlu dieksplorasi seperti di wilayah Sumatera, Kalimantan, Jawa Bagian Selatan. Romusha ini juga dapat di ekspor ke luar negeri seperti Singapore, Filipina, Malaysia, dan Birma. Tentu pengaturan suplai tenaga kerja dilihat melalui tingkat kebutuhan dan hasil yang ingin dicapai oleh Pemerintah Militer Jepang di ketiga wilyah administratif.

Untuk angka pengerahan ini banyak peneliti mengajukan sumber yang berbeda-beda. Para peneliti yang membahas romusha seperti Kurasawa, Sato, Raben, menyebutkan data romusha yang dikirimkan ke wilayah Asia Bagian Selatan dan Pasifik sebanyak 300.000 orang Jawa. Namun Kurasawa menggunakan dokumen dari Jepang mengungkap jumlah romusha yang dimobilisasi oleh Pemerintah Militer Jepang, mencapai jumlah 4 juta jiwa. (Kurasawa, Aiko. 1993). Tetapi menurut Kepala Militer Jepang di Pulau Jawa, Yamamoto, jumlah tenaga kerja yg dikirim jumlahnya hanya sekira $\quad 140.000$ sampai 160.000 orang 
(Nishijima dalam Herkusumo, 1982). Jumlah pengerahan tenaga kerja ini masih simpang siur karena sulitnya menemukan dokumen detil untuk pengerahan tenaga kerja massal di wilayah Hindia Belanda. Apalagi antara jumlah romusha yang dikirim keluar Pulau Jawa, di dalam Pulau Jawa, romusha tetap dan romusha sementara, serta klasifikasi persis usia yang dipaksa bekerja, masih belum jelas.

Terlepas dari persoalan tersebut dari penelitian yang ada hampir seluruhnya menujukan pola yang sama. Pekerjaan yang mereka lakukan itu banyak terkonsentrasi membangun infrastruktur dan eksploitasi sumber daya alam untuk kepentingan perang, seperti: mengupulkan bahan pangan seperti padi dan tanaman obat-obatan, membuat jalan, jembatan, jalan raya, rel kereta api, landasan pesawat terbang, dan menggali bahan tambang. Pekerjaan itu dilakukan dengan memanfaatkan penduduk yang tersebar di seluruh Indonesiakhususnya penduduk di Pulau Jawa bagian tengah. Hal itu dilakukan dengan cara propaganda pihak militer jepang dan para kolabolator pemerintah Republik Indonesia. Sehingga perintah tersebut menjadi efektif untuk memobilisasi masyarakat terutama yang ada di Pulau Jawa.

Beberapa penelitian yang terkait langsung dengan romusha di Indonesia antara lain seperti, Kurasawa (1993) berbicara mengenai studi tentang perubahan sosial di pedesaan Jawa, yang menyoroti mobilisasi masyarakat desa melalui aparat lokal dan kondisi romusha secara umum pada konteks itu. Lalu tulisan Poeze (2006), mengungkap pekerja paksa yang berasal dari jawa dipergunakan membangun jalan kereta api dari Bayah menuju Saketi untuk keperluan pengangkutan dan mengali tambang batu bara di Bayah, Banten, Jawa Barat.

Lain halnya dengan Raben (2003), membahas pengerahan romusha di wilayah timur seperti Celebes (Sulawesi), Moluccas (Maluku), New Guinea (Irian Jaya), dan Borneo (Kalimantan) dengan memanfaatkan masyarakat lokal dan orang dari Pulau Jawa. Penelitian lain yang dibahas Sato (2003) mengenai mobilisasi penduduk Jawa sebagai Romusha namun untuk kepentingan pertanian (menanam padi) sebagai pasokan pangan tentara Jepang untuk berperang dengan sekutu. Kemudian Romusha, Kisah Seorang Tawanan Jepang yang ditulis oleh Thompson, yang merupakan autobiografi sebagai seorang tawanan perang tentara jepang yang merupakan tentara Angkatan Udara (pilot) Selandia Baru. Di dalam bukunya ia menceriterakan sebagai salah satu tentara sekutu yang ditangkap tentara Jepang dan dipindah antarcamp - Jawa, Ambon, Haruku, dan Sumatera - untuk ditawan dan melakukan kerja paksa yaitu membangun rel kereta api dan landasan pesawat terbang. Kisah palang dramatis diceriterakan melalui pengalaman yeng penuh kengsengsaraan ketika membangun landasan pesawat terbang dan membuat rel kereta api-bersama dengan tawanan perang lain dan romusha dari Jawa.

Beberapa hasil riset dan kisah nyata tersebut menegaskan terjadi pengerahan massa besar-besaran di hampir seluruh wilayah Indonesia oleh Pemerintahan Militer Jepang. Proses mobilisasi massa tersebut merupakan solusi kurangnya sumber daya tentara Jepang karena mereka telah mengalami banyak kekalahan di front battle menghadapi Pasukan Amerika dan sekutu. Beberapa hasil riset tersebut lebih banyak memotret fungsi romusha yang beragam di lapangan da aspek dari pola pengorganisasisan para romusha di pelbagai wilayah di Indonesia. Terlihat antara hasil penelitian yang satu dengan yang lain menjadi saling melengkapi.

Umumnya Militer amat menekankan perangkat desa untuk mengerahkan dan mengeksploitasi tenaga kerja dilakukkan juga dengan cara paksaan dan tipuan. Mengalami paksaan jika korban yang ditunjuk tidak berhasil ditipu dengan iming-iming mendapat upah dan makanan yang layak.

Penelitian awal yang saya temukan ketika menapaki wilayah Boyolali menemukan kasus di satu desa yang seluruh penduduk desanya dijadikan romusha. Sedikit ada perbedaan dan kemiripan ketika saya melakukan penyelidikan hasil penelitian mengeni romusha di Indonesia. Pada observasi awal di Boyolali saya melihat mengapa ada disain konsentrasi pertahanan militer Jepang di wilayah tersebut? Hal ini mirip dengan romusha yang membangun fasilitas pertahanan militer seperti di Kaliurang dan Mranggi Jateng (Suwarno, PJ. 1999). Mereka diperintahkan untuk membuat gua dan parit pertahanan, kemudian penduduk diperintahkan untuk menanam tanaman obat (organik) guna kepentingan militer di garis depan. Kemungkinan wilayah Jawa Tengah di Jogjakarta termasuk wilayah Sleman (kaliurang) di wilayah lereng Merapi akan dijadikan benteng pertahanan Militer Jepang dari gempuran sekutu. Hal itu akan terlihat di posisi Selo yang membelakangi posisi Kaliurang

Daerah Selo Kabupaten Boyolali sebelum jaman pendudukan Jepang merupakan wilayah perkebunan Kopi, Kina, dan Tebu (komoditi ekspor) milik Belanda. Lahan tersebut 
menempati sekitar areal pemukiman penduduk setempat. Komoditi yang lain hanya berupa tanaman sayur untuk memenuhi kebutuhan penduduk setempat saja (subsisten). Kontur tanah dan wilayah geografis berbukit-bukit. Daerah ini kurang ideal kalau dijadikan sebagai tempat lumbung pangan beras. Karena padi tidak dihasilkan dalam skala berlimpah, namun lebih kepada padi huma (ladang) dan aneka jenis sayur-sayuran seperti kol, sawi, singkong, dan pohon pisang.

Temuan riset awal mengindikasikan pada saat Militer Jepang menguasai wilayah tersebut, mereka melakukan kebijakan kerja paksa (romusha). Di dalam satu desa hampir semua orang, baik anak-anak yang berumur 5 tahun sampai orang tua yang berusia sekitar 40 tahun, menjadi romusha. Hal itu dilakukan untuk mempercepat target pekerjaan membangun goa dan parit pertahanan yang telah direncanakan oleh Militer Jepang. Karena kontur wilayah yang sulit serta berbukit dan berada di areal pegunungan.

Perintah langsung dari militer jepang ditujukan kepada bupati, camat, kemudian langsung kepada kepala desa dan perangkat desa. Melalui kepala desa tersebut dikumpulkan ketua dusun dan perangkat desa dan jagabaya (RT setempat) serta beberapa tokoh masyarakat. Kemudian pengorganisiran dilakukan dengan memanfaatkan hirarki institusi tersebut dari level atas sampai level bawah. Cara-cara tersebut tergolong efektif, karena mampu memobilisasi masa dengan cara relatif mudah dan masif.

Kepala desa serta perangkat desa merupakan penggerak mobilisisasi efekif dan cepat. Melalui cara tersebut masyarakat relatif mudah dikumpulkan. Mereka didatangi ke rumah oleh para perangkat desa untuk dimintai datang ke kantor kepala desa bekerja untuk kepentingan desa. Melalui alasan kepentingan desa tersebut masyarakat desa direkrut untuk kepentingan kerja paksa.

Alasan tersebut dipakai untuk memobilisasi penduduk secara masif di desa tersebut. Perantara yang paling cepat membawa berita mengabarkan ke setiap rumah penduduk adalah kurir lokal atau bagian dari perangkat desa (kepala dusun). Mereka memberitahukan bahwa setiap orang yang dipanggil sesuai dengan nama diwajibkan datang pada hari yang telah ditentukan ke tempat kepala desa.

Di balai desa kemudian hari mulai berdatangan orang sesuai dengan waktu yang diatur sebelumnya ada yang datang pagi, siang, dan sore hari. Tidak ada yang mengetahui waktu itu mau dijadikan apa, instruksinya membantu kegiatan kerja bakti untuk membangun desa. Setelah bertemu langsung dengan kepala desa mereka baru mengetahui ditugasi untuk apa. Tampaknya kepala desa telah diinstruksikan oleh otoritas yang lebih tinggi untuk memberikan perintah langsung kepada penduduk desanya. Pada waktu itu setiap rumah tangga diwajibkan mengirimkan tenaga kerja satu orang. Namun pada praktiknya kemudian malah ada yang satu rumah tangga akhirnya menjadi romusha. Terdiri dari 7 orang anggota rumah tangga yang menjadi romusha dengan pekerjaan yang berbeda satu sama lain. Ada yang menggali, bekerja mengangkut kayu jati glondoingan (untuk penyangga fondasi gua), sebagai pengangkat sisa tanah, dan mengangkat pasir serta memasak ransum untuk para pekerja (biasanya dilakukan perempuan).

Sesuai dengan ketetapan kepala desa lebih lanjut ia memerintahkan bahwa besok atau beberapa hari kemudian warga yang telah dipanggil ke balai desa diwajibkan datang ke Kecamatan Selo. Di sana orang dari berbagai penjuru desa yang ada di Selo berkumpulkan mendengarkan pidato propaganda camat (ken).

Mereka kemudian berkumpul di areal lapangan daerah yang bernama Cepogo Kecamatan Selo. Masing-masing orang telah dibebani kerja oleh kepala desa. Mereka ada yang diperintahkan untuk menggali gua, mengangkat tanah dari galian, kemudian juga ada yang bertugas mengangkat kayu untuk penyangga gua setelah digali. Ada pun orang yang bertugas untuk mengangkut kayu dan peralatan galian dari kecamatan merupakan orang yang yang berusia relatif muda (berkisar usia 40-65 tahun) atau orang tua yang masih sehat. Kerap kali perempuan dilibatkan untuk bekerja mengangkut kayu tersebut. Pekerjaan mengangkat kayu dilakukan secara bergiliran sesuai dengan jarak tempuh. Maksudnya untuk setiap jarak sekitar $10 \mathrm{Km}$, secara bergantian mengangkutnya.

Untuk yang menggali tanah dan batu yang kemudian menjadi gua dibutuhkan sekitar 2-3 penggali, sisanya sekitar 4 orang membuang hasil tanah galian keluar gua. Hal itu dilakukan secara kontinyu menurut pengakuan informan yang menggali bekerja siang dan malam, dari mulai pukul 7 pagi sampai pukul 4 sore, istirahat sebentar kemudian berlanjut lagi dari pukul 6 sore sampai 2 pagi. Untuk satu gua yang bertugas menggali di dalam jumlahnya berkisar 6-8 orang. Pekerjaan penggalian ditargetkan setiap hari minimal, sampai 1 meter untuk panjang, ketinggian, dan lebar masingmasing 1 meter. 

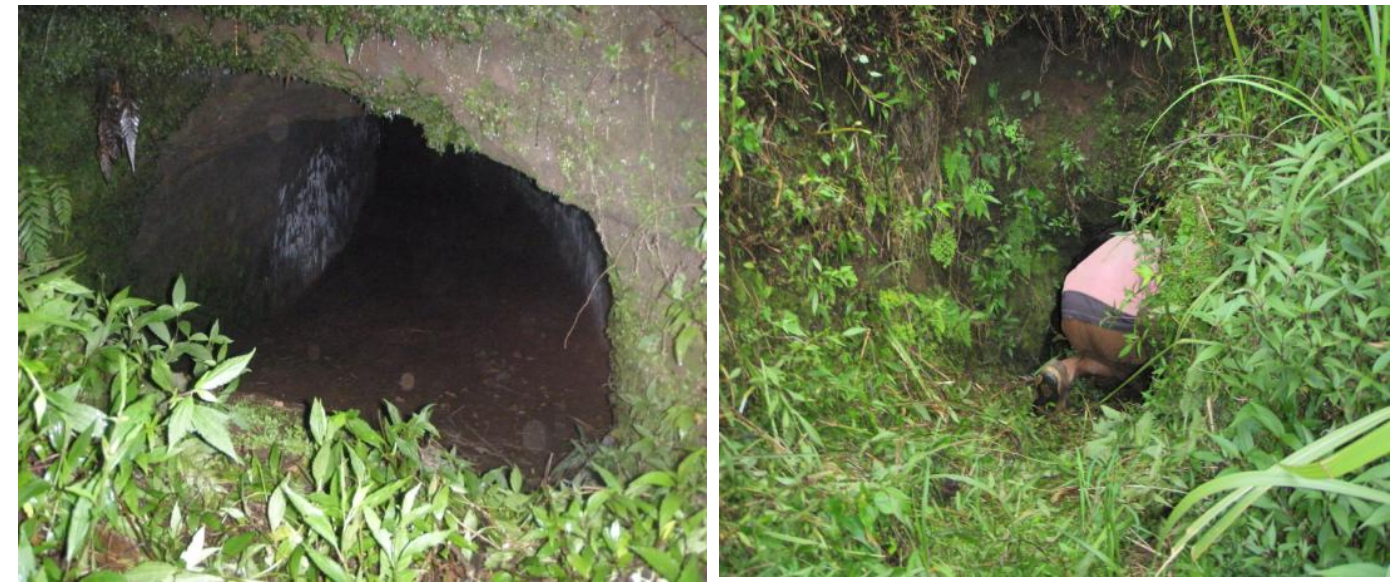

Gambar 1. Gua Jepang Yang Ditemukan Ketika Penelusuran Di Daerah Pegunungan

Alat-alat yang digunakan untuk menggali berupa linggis panjang, palu bodhem (palu besar pemecah batu), cangkul, skop, ember kaleng. Jika penggali menemukan batu besar mereka melapor kepada pengawas di luar gua. Kemudian pengawas lokal tersebut langsung memberitahu petugas patroli yang ada di lokasi atau langsung ke kecamatan. Tidak lama kemudian datang patroli tentara Jepang membawa dinamit untuk meledakkan batu yang menghalangi penggalian gua. Pemasangan dinamit dilakukan oleh tentara dan mereka yang meledakannya. Setelah itu reruntuhan batu tersebut dibereskan oleh romusha pengangkut tanah dan batu.

Salah satu informan Mrj (86 tahun) mengisahkan pengalaman pahitnya tersebut: "Saya bekerja sebagai penggali seolah tidak ada hentinya. Di bawah tanah, dengan kondisi udara yang dingin. Baju dan celana yang digunakan hanya terbuat dari bahan goni (bahan pembuat karung goni). Pakaian tersebut jika dipakai di dalam kondisi lembab, menyebabkan gatal-gatal karena terdapat kutu. Penerangan juga terbatas, karena hanya menggunakan obor. Sebisa mungkin anggota grup yang terdiri 8 orang di dalam satu gua bekerja sama, agar tidak terlampau letih. Jika ada yang sakit maka teman saya tersebut akan istirahat satu hari di rumah. Namun jika kedapatan hanya sakitnya dibuat-buat maka akan menanggung risikonya. Suatu saat ada yang pernah berbohong sakit supaya bisa istirahat. Namun ketika diperiksa ke rumah dan dicek oleh pengawas (antek-antek Jepang) dan mantri ternyata tidak apa-apa. Maka teman saya itu dipukuli oleh beberapa orang sampai babak belur oleh petugas pengawas yang merupakan orang suruhan Militer Jepang. Setelah itu tidak ada yang berani lagi berpurapura sakit”.

Mereka bekerja sesuai dengan perintah awal seperti menggali lubang, membawa kayu, serta mereka yang menguruk tanah untuk parit. Jika ia bekerja sebagai penggali lubang, maka ia akan melakukan pekerjaan itu terus menerus (tidak ada sistem rolling kerja). Pengangkut tanah, maka pekerjaanya itu terus setiap harinya. Kecuali ada kebijakan yang berubah berdasarkan rekomendasi aparat pemerintah ke pejabat atau staf militer Jepang yang bertugas di daerah itu. Misalkan orang tersebut memiliki keahlian tertentu atau ia merupakan anak dari seorang yang berpengaruh di desa.

Untuk mereka yang berkerja di penggalian goa kebanyakan adalah orang yang memiliki status sosial yang rendah. Sebelum Jepang masuk mereka hanya petani buruh atau orang yang bekerja serabutan di desa. Bagi aparat pemerintahan dan elit desa golongan ini yang paling banyak dipilih. Karena mudah untuk dipengaruhi dan sangat patuh terhadap perintah otoritas lokal. Pengawasan di lapangan dilakukan oleh orang yang diperaya tentara Jepang untuk mengawasi para pekerja. Beberapa orang ini disebut oleh penduduk setempat disebut antek-antek Jepang. Perlakuan mereka terhadap romusha menurut informasi lebih galak dari pada tentara Jepang yang berpatroli di desa. Artinya antek-antek itu lebih sering berbuat kasar dengan menampar atau memukul romusha yang melakukan kesalahan. 
"Antek-antek Jepang itu orang yang memiliki ilmu silat di sini sebagai tukang pukul ada dari orang sini dan desa lain. Mereka biasanya kerap berbuat kasar terhadap romusha yang tidak bekerja rajin. Malah pernah waktu itu mereka juga menggambil ternak sapi dari penduduk, dengan alasan untuk keperluan tentara Jepang. Meski dilakukan barter hewan ternak dengan beberapa helai pakaian atau selimut" ujar pria sepuh ini. Perlakuan antek-antek Jepang kasar terhadap penduduk, memaksa dan menggunakan caracara intimidasi. Kepala desapun kerapkali tidak berkutik menghadapi ulah mereka, karena katanya mereka mendapat perintah langsung dari markas tentara Jepang yang ada di Kecamatan Selo.
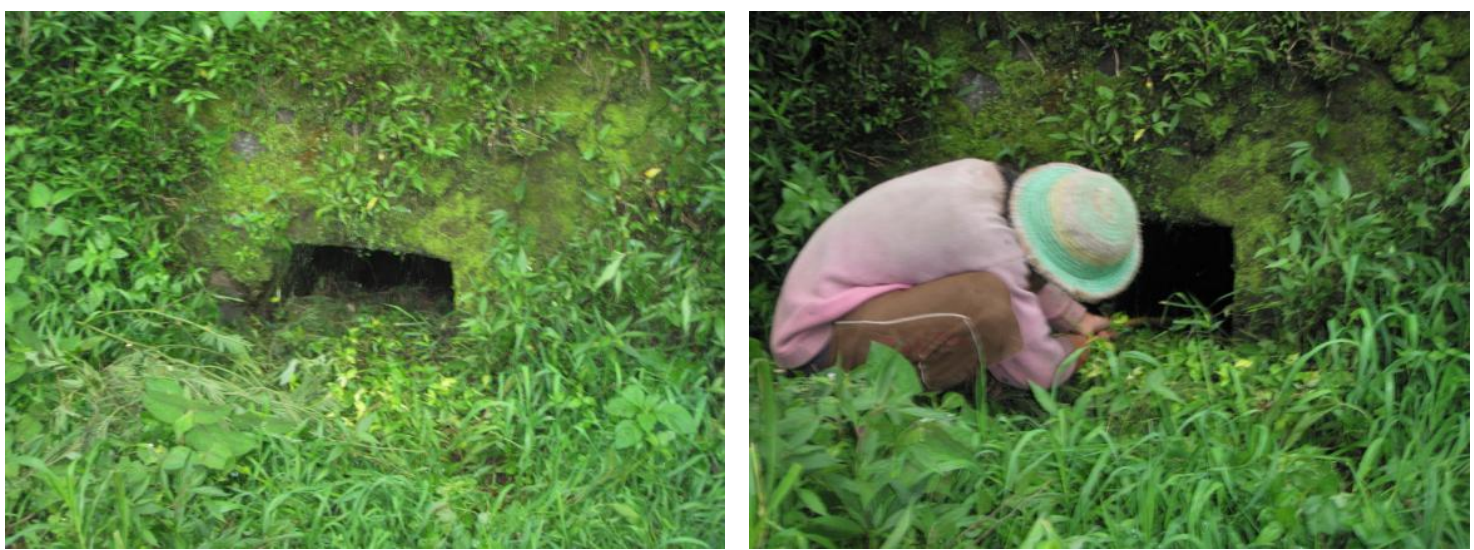

Gambar 2. Lubang Di Sepanjang Gua Sebagai Pos Pengamatan Dan Pengintaian Di Luar

Untuk kerja yang relatif ringan biasanya dapat diperoleh oleh orang yang berasal dari golongan ekonomi ke atas. Misalnya anak seorang kiyai, tokoh adat, dan masyarakat setempat. Apalagi jika ia orang yang relatif sudah mengenyam pendidikan dasar (Sekolah Rakyat), biasanya dipekerjakan sebagai juru tulis atau kurir surat. Kalaupun bekerja fisik ia hanya sekadar mengangkat kayu atau batu, tidak bekerja berat seperti menggali gua. Waktu bekerja pun hanya sekira 5-7 jam, tergantung kondisi dan kebutuhan saat itu. Malah Im (88 tahun) mengungkapkan: "Waktu itu anak lakilaki dari kepala desa juga ikut bekerja sebagai pengangkut kayu. Namun ia bekerja tidak lama paling sekira 3-4 jam. Itu pun banyak istirahat dan diganti dengan pekerja lain. Tidak ada anak atau keluarga dari perangkat desa yang disuruh bekerja sebagai penggali gua”.

Hal itu tenyata juga dialami oleh Im, terungkap bahwa ia juga bekerja sebagai pengangkut kayu hanya sekitar 6 bulan. Karena ayahnya merupakan kiyai di desa itu, maka ia mendapat perlakuan khusus dipindahtugaskan sebagai kurir surat di Desa Rogobelah dan kecamatan Selo. Di samping itu ia pernah mengenyam pendidikan sampai kelas IV (Sekolah Rakyat), sehingga dapat membaca dan menulis honocoroko (aksara Jawa). Karen posisi dan kategori sosial tersebut ia tidak yang bekerja berat sebagai romusha sampai akhir masa pendudukan militer Jepang berakhir.

Selain romusha yang berasal dari desa setempat, ternyata rupanya juga ada dari daerah lain seperti dari Banyumas, Solo, dan Magelang. Mereka yang didatangkan dari tempat tersebut juga ternyata mengerjakan pembuatan gua.

Di tempat penggalian menurut salah satu informan mereka ada yang berasal dari luar desa di kecamatan Selo, atau Boyolali. Mereka ini biasanya ditugasi untuk pembuatan gua dan mengangkut kayu. Kerap kali juga mereka mendapat tugas menjadi pengawas regu di dalam satu gua. Meski sebagai mandor, namun mereka tetap bekerja seperti yang lain sesuai dengan tugas yang diberikan. Mandor sifatnya hanya sebagai koordinator yang mengatur agar pekerjaan berjalan sesuai yang diinginkan. Untuk tempat tinggal, orang yang berada di luar desa disediakan rumah tinggal di desa dekat dengan Gunung Merbabu dan Gunung Merapi. Namun untuk yang tinggal di desa sebelah mereka tetap pulang ke rumah masing-masing. Rumah tinggal tersebut merupakan rumah bilik milik warga yang digunakan untuk tempat bermukim romusha yang bekerja di situ.

Daerah tersebut mayoritas penduduknya bekerja sebagai petani yang memiliki lahan dibawah 0,5 Ha, buruh tani, dan buruh perkebunan milik Belanda. Ketika Jepang melakukukan mobilisasi massa, maka pola mata 
pencaharian masyarakat sebelumnya berubah. Peristiwa tersebut membuat kehidupan ekonomi praktis tidak berjalan normal dan lumpuh. Untuk membantu kehidupan romusha ada ransum dari Pemerintahan Militer Jepang melalui suatu mekanisme berupa pemberian bahan makanan-beras dua cangkir seminggu dua kali dan beberapa sendok makan garam.

Untuk mengambil jatah makanan tersebut romusha harus ke kecamatan mengambilnya. Namun jika berhalangan dapat diwakilkan oleh salah satu anggota rumah tangga. Seperti diungkapkan oleh $\mathrm{Mj}$ (86 tahun): "Setiap rumah tangga menerima bantuan untuk hidup berupa beras (campuran grontol atau gabah) dan garam, yang jumlahnya sangat terbatas. Apalagi memunyai anggota rumah tangga yang banyak, harus bisa mengaturnya. Karena jumlah makanan terbatas namun kerja berat. Sehingga saya pun terpaksa sepulang kerja mencari tambahan lauk sayuran di areal kebun dan perbukitan. Meski kekurangan makan kami sekeluarga (berjumlah 6 orang) semuanya tidak ada yang meninggal karena kelaparan. Namun untuk dibeberapa tempat seperti di desa lain terdengar ada yang meninggal karena rasa letih dan kurang makanan. Ketika hendak mengambil jatah makanan sepulang kerja mengangkat kayu saya harus menapki jalan yang jaraknya cukup jauh. Saya tidak ingat lagi tepatnya berapa lama, namun didalam perjalanan kaki terasa pegal-pegal dan letih. Belum lagi ketika sampai di sana saya harus mengantri dengan lama. Banyak orang dari desa lain yang mengambil jatah makanan tersebut".

Berdasarkan klasifikasi kerja mereka ada pelbagai macam pekerjaan yaitu berat (menggali gua), sedang (mengangkat kayu), dan ringan (mengali parit atau memasak). Namun pada kenyataanya klasifikasi pekerjaan tersebut tidak terkait dengan jatah makanan yang diterima. Semua terlihat disama-ratakan untuk yang mendapatkannya.
Pemberian bahan makan romusha ditangani oleh Pemerintahan Militer Jepang, namun tetap sebagai tenaga operasional menggunakan otoritas setempat. Pada kenyataannya upah minim berupa beras kualitas rendah tersebut tidak diterima sesuai dengan yang dijanjikan. Padahal ketika mereka disuruh melakukan kerja paksa, dijanjikan oleh pihak yang pemerintah lokal akan mendapat upah yang besarannya sesuai dengan kerja yang dilakukan. Kemudian akan mendapatkan makanan dan pakaian yang layak. Namun hal itu tidak menjadi kenyataan dikemudian hari. Para pekerja hanya makan nasi (kerap kali encer) dengan ikan asin atau sayur atau pelepah batang pisang. Itu pun lama kelamaan yang dapat dimakan hanya bubur encer (campur gabah), tanpa lauk pauk.

Untuk jumlah goa Jepang yang digali pun masih simpang siur. Menurut beberapa orang sepuh di desa ada yang mengatakan 9 goa, 11 goa, atau 12 goa. Beberapa penduduk yang sudah sepuh dan aparat desa mengatakan beberapa goa tertutup dan longsor tertimbun tanah, sehingga banyaknya tidak teridentifikasi lagi.

Beberapa bulan sebelum Jepang menghilang tahun 1945 dari desa tersebut. Gua yang berhasil dibangun menurut Mrj (86 tahun) sebanyak 9 di areal Gunung Merapi. Kemudian ditambah dengan yang di daerah pegunungan Merbabu sebanyak 4 gua. Rupanya ia sempat dipindah tugas ke desa lain yang lokasinya dekat dengan kaki gunung Merbabu. Menurut pengakuannya panjang gua yang digalinnya sudah tidak dapat terhitung lagi. Namun pria kecil yang terliat ramah ini mengakui beberapa gunung yang ada di areal Gunung Merapi tembus sampai ke belakang, menghadap hutan dan jurang. Lokasi geografis yang ekstrem membuat pelacakan gua menemui kendala, namun berhasil ditemukan beberapa gua.
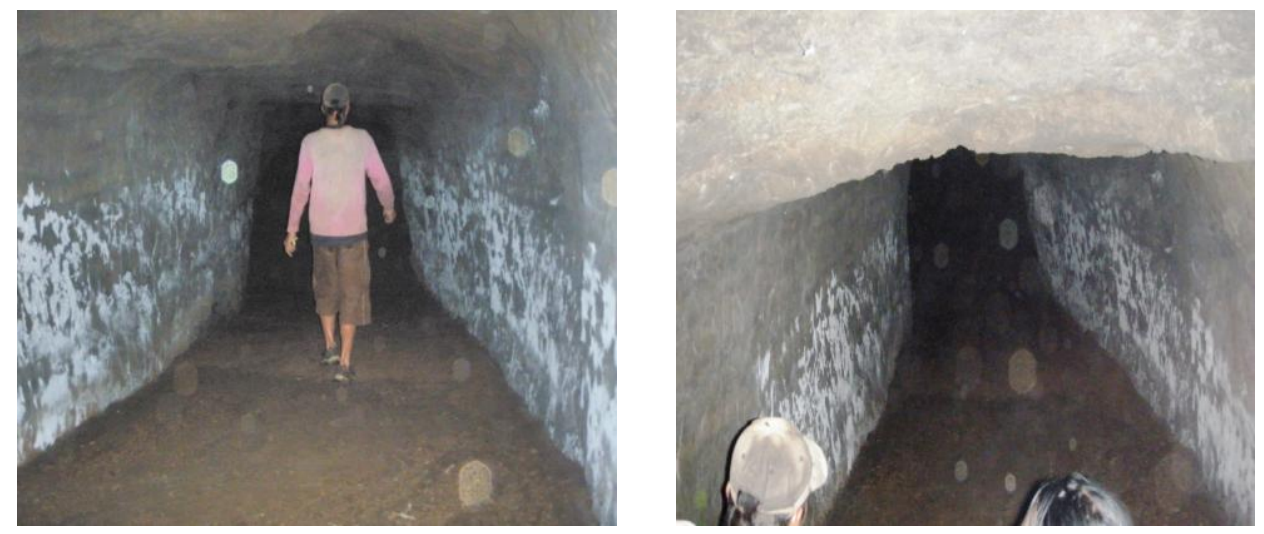

Gambar 3. Gua Yang Berhasil Digali Oleh Romusha 
Untuk memastikan pada waktu itu dilakukan ekspedisi pencarian gua Jepang yang ada di sekitar areal perbukitan. Akhirnya ditemukan gua sebanyak delapan, sisanya tertimbun oleh tanah. Hasil penelusuran tersebut membuktikan bahwa desa ini menjadi salah satu basis pertahanan yang berada di Jawa Tengah. Kemungkinan lokasi geografis untuk wilayah pertahanan sangat memungkinkan, berada di wilayah dataran tinggi, hutan, dan pegunungan.

Menelusui jejak peninggalan gua di areal gunung sungguh melelahkan, rupanya penduduk lokal pun jarang ada yang tau keberadaan situs ini. sehingga sulit untuk melacak keberadanya. Lokasinya juga berada di atas, sehingga membutuhkan fisik yang prima untuk mencapai beberapa titik gua. Gua tersebut konon tembus sampai ke belakang, namun karena kerap terjadi aktifitas tektonik Gunung Merapi, terjadi longsor tanah. Itu menyebabkan kondisi gua cepat tertutup oleh tanah seperti yang terlihat pada gambar III. Lebar gua hampir mencapai kurang dari 1,5 meter dan tinggi sekitar 2 meter. Kondisi lembab dan dingin cukup menyengat jika berada di dalamnya.

Untuk Anak-anak yang usia 8 -15 tahun pun tidak luput dari aktifitas romusha. Karena mereka juga membantu untuk mengangkut tanah dari lubang yang dijadikan seperti parit untuk perlindungan tentara. Parit ini memiliki kedalaman sekitar 1 meter sampai 1,5 meter, dengan panjang yang beragam. Biasanya anakanak ini dilibatkan sepulang sekolah atau siang hari. Mereka dikumpulkan oleh orang lokal yang memiliki kedekatan terhadap Militer Jepang (antek Jepang). Tidak seperti romusha yang didata dan dikumpulkan oleh pihak desa. Romusha anak-anak ini setiap hari dipanggil, kemudian berkumpul dan melaksanakan kerja ditempat yang telah ditentukan. Untuk makan biasanya mereka diberikan nasi encer atau jika tidak ada, mereka tidak makan apa-apa.

Tidak ada niat sedikit pun untuk menolak apalagi melarikan diri. Karena akibat hirarki yang begitu kuat akibat proses kolonialisasi Belanda, masyarkat desa sangat tunduk dan takut dengan pengaruh otoritas lokal tersebut. Di samping itu juga belum ada informasi mengenai keadaan yang sebenarnya, sehingga banyak yang tidak paham dengan kondisi yang tengah terjadi.

Kemunculan tentara dengan topi hijau berlambang bintang (Rikugun), pun diakui oleh beberapa informan yang melihatnya. Jumlahnya yang berpatroli dan mengawasi di sana berjumlah sekitar 4-5 orang. Dijelaskan bahwa ada yang menggunakan seragam hijau dengan senapan laras panjang dilengkapi bayonet, ada juga yang membawa pistol di pinggangnya. Mereka ke desa menggunakan jeep, kemudian kerap kali mengunjungi lokasi goa, untuk mengontrol kemajuan pekerjaan yang telah diinstruksikan sebelumnya. Jika ada yang tidak beres dilapangan, mereka konon tidak main pukul, namun marah atau menyuruh mandor (pengawas lapangan) yang melakukan tindakan hukuman (dipukul atau jatah makan tidak ada).

Pemobilisasian massa (romusha) ini jelas dilakukan untuk membuat basis pertahanan militer yaitu dengan membangun goa di areal pegunungan. Serta, konon penduduk juga diperintahkan menaman tanaman yang diyakini sebagai obat untuk menyembuhkan luka. Namun anehnya belum terlihat konsentarasi pasukan di wilayah tersebut memasuki pertengahan tahun 1944. Namun sudah ada tempat bahan pangan di seputar areal goa berupa kandang ayam dan kandang sapi yang di bangun romusha.

Informasi menyatakan bahwa tentara Jepang yang ditugasi menjaga hanya sebanyak lima orang. Mereka datang di pagi hari, siag hari, dan malam hari secara berggantian mengontrol target pekerjaan bersama dengan aparat dari desa atau kecamatan. Hal itu dilakukan terus sampai mereka kalah perang dengan sekutu dan akhirnya pergi meninggalkan begitu saja romusha-nya tanpa pemberitahuan apa-apa.

Untuk angka yang pasti mengenai pengerahan massa yang membangun infrastruktur goa tersebut belum dapat terlacak. Karena keterbatasan dokumen yang mendukung temuan dilapangan terkait dengan pengerahan massa secara masal. Beberapa kesaksian eks romusha yang masih tersisa hidup saat ini memang mengatakan bahwa seluruh penduduk desa pada waktu Jaman Jepang dipaksa bekerja.

Pasca hengkangnya Jepang, membawa luka bagi masyarakat desa karena begitu kerasnya sistem kerja paksa yang diterapkan. Pasca dibomnya Hirosima dan Nagasaki, terdengar kabar Jepang kalah perang saat itu pun kondisi desa menjadi sepi. Tidak ada lagi tentara patroli Jepang yang datang melakukan inspeksi. Penduduk pun mulai tidak aktif lagi dalam pekerjaan yang ditugasi sebelumnya. Untuk itu penduduk yang menjadi romusha mulai membubarkan diri ke tempat masing-masing.

Riset pada tahap awal tersebut diharapkan mampu menemui pengembangan dan analisis pada kasus mikro di suatu wilayah. Di mana praktik kerja paksa secara masif dan masal 
dilakukan di desanya sendiri, tidak peduli dengan batasan usia dan gender.

\section{Redupnya Isu dan Gerakan Kemanusiaan Romusha}

Pasca menyerahnya Militer Jepang kepada sekutu, apakah ada penyelesaian untuk masalah invasi militer Jepang di Indonesia? Setahu saya pernah ada Pengadilan Militer Internasional untuk Timur Jauh (International Military Tribunal for the Far East (IMTFE), juga dikenal dengan Pengadilan Kejahatan Perang Tokyo, yang mulai diselenggarakan pada $3 \mathrm{Mei}$ 1946 sampai 12 November 1948 dibuat dengan tujuan untuk mengadili para pemimpin kekaisaran Jepang atas pembantaian manusia di Nanking dan kejahatan kemanusiaan selama Perang Dunia ke-II.

Namun ternyata hal itu, tidak menyentuh persoalan kejahatan perang yang terjadi spesifik di Indonesia - salah satunya pengerahan kerja paksa (romusha). Paling santer yang dibahas hanya ganti rugi kepada (Prison of War) POW sekutu yang dijadikan romusha selama masa perang. Ini membuktikan pengadilan tersebut lebih banyak membahas kerugian di pihak sekutu.

Namun kemudian, di San Francisco, Amerika Serikat 6 tahun 1951 digagas suatu pertemuan Perundingan Perjanjian Damai dan Pampasan Perang dengan Jepang (Perjanjian San Francisco), yang bermaksud menuntaskan penyelesaian masalah PD ke-II. Indonesia kemudian diundang atas dasar sebagai negara bekas pendudukan Jepang. Pada waktu itu RI (pada masa PM. Djuanda) memutuskan ikut karena waktu itu melihat manfaat dan kuntungan yang akan didapat dari perjanjian tersebut. Pada 20 Januari 1958, menindaklanjuti hasil Perjanjian San Francisco, pemerintah Indonesia menandatangani perjanjian bilateral yang berisi kesepakatan ganti rugi RI - Jepang.

Di dalam perjanjian perdamaian yang memunculkan kesepakatan Pampasan Perang RI-Jepang ternyata tidak menyinggung sedikit pun ganti rugi secara personal terhadap para korban (romusha, ianfu, dan heiho). Persoalan yang mengemuka malah membahas kerugian materil dengan perencanaan pembangunan fisik negara-melalui Dewan Ekonomi dan Pembangunan dan kementrian yang terkait. Alhasil persoalan kejahatan kemanusian Militer Jepang menjadi terkunci rapat melalui perjanjian tersebut. Perjanjian ini menurut saya menjadi penyelesaian "sapu jagad", untuk mengaburkan persoalah kejahatan perang yang sebenarnya.
Proses penyelesain langsung kepada korban romusha sirna sudah. Namun secara seiring waktu ada perkembangan yang mengejutkan sekitar April 1993. Bahwa ada informasi dari Federasi Asosiasi Advokad Jepang (Nichibenden) yang akan melakukan usaha pengumpulan korban invasi Jepang 19421945 di Indonesia. Hal itu dilakukan guna kepentingan acara simposium di Jepang mengenai persoalan korban invasi Jepang. Persoalan tersebut mengemuka karena terkait kencangnya persoalan isu budak seks tentara Jepang (jugun ianfu) melalui desakan internasional negara korban lain seperti Korea Selatan dan Taiwan pada waktu itu. Kemudian, diperkuat oleh pernyataan permintaan maaf secara resmi PM. Miazawa pada Rabu 4 Agustus 1993 kepada sekitar 10.000 perempuan yang dipaksa menjadi pelayan seks penghibur tentara Jepang sebelum dan selama berkobarnya PD ke-II. Itulah momentum di mana persoalan ianfu dan romusha menjadi terkuak kembali di Indonesia.

Melalui tokoh monumental Alm. Mardiyem (Momoye) yang mengadukan nasibnya ke LBH Yogyakarta, persoalan romusha ikut mencuat kembali. Setelah Mardiyem melaporkan kisahnya ketika menjadi Ianfu jaman Jepang, banyak surat kabar lokal yang meliput berita ini. Hal itu mendorong salah seorang ex-romusha bernama Amat Karto bin Tohir (83 th) warga Karanggondang, Pendowoharji-Bantul mengadukan nasibnya ke LBH Yogjayakarta yang diterima oleh Humasnya, Budi Hartono (Kompas, 29 APRIL 1993). Berita itu pun diliput terus oleh media lokal, tak pelak banyak orang yang tahu mengeni persoalan tersebut.

Efeknya tentu saja, banyak berdatangan orang-orang yang mengaku sebagai korban romusha. Korban berbondong-bondong datang untuk mendaftar karena mendengar isu akan ada ganti rugi dari pihak Jepang. Banyak yang berdatangan selama kurun waktu enam bulan tersebut di-screanning kembali oleh LBH Yogjakarta, sehingga ketika bulan September ex- romusha yang berhasil terdata mencapai angka sekira 17.000 orang (berasal dari Jakarta, DIY, dan Jawa Tengah bagian selatan). Sebenarnya masih banyak yang belum terdata, namun YLBHI terganjal segala persiapan untuk keberangkatan termasuk menyiapkan data base korban perang, yang akan diajukan awal Oktober 1993 saat konfrensi di Jepang.

Pendataan tersebut YLBHI merupakan mementum untuk membawa persoalan romusha dan ianfu melalui Konfrensi di Tokyo. Pada konfrensi tersebut YLBHI berencana akan 
menyampaikan tuntutan, antara lain yaitu: a) Tuntutan ganti rugi kepada korban, b) Permohonan maaf resmi pemerintahan Jepang di publik langsung kepada korban, dan c) Dimasukan persoalan ini dalam kurikulum sekolah atau lembaga pendidikan di Jepang.

Gerakan YLBHI ini rupanya tanpa memperoleh dukungan dari DPR dan pemerintah RI pada waktu itu-hanya sekadar komentar dukungan moral (Kedaulatan Rakyat, Sabtu 22 Mei 1993). Ini membuat YLBHI yang merupakan lembaga swadaya masyarakat (LSM) tidak mendapat dukungan politik penuh, sehingga berjalan sendiri. Ini yang menyebabkan YLBHI "angkat tangan" sehingga tidak mampu memperjuangkan tuntutan tersebut di kancah Internaional di kemudian hari.

Hal itu bukan tanpa musabab, Indonesia sepertinya enggan mendukung kasus tersebut. Faktor utama disinyalir banyaknya nilai investasi Jepang di Indonesia yang membuat khawatir hubungan kedua negara akan terganggu. Alhasil pemerintah Jepang pun melalui Duta Besar dan Sekertaris Kedubes Jepang di Jakarta, membela diri dengan mengatakan Pemerintah Jepang dalam hal ini menolak tuntutan ganti rugi, pasalnya menganggap masalah yang berkaitan dengan PD ke-II itu sudah diselesaikan melalui perjanjian perjamaian pampasan perang tahun 1958.

Kasus Romusha di dunia International ramai dibicarakan kembali tahun 2007. Seperti yang dilakukan oleh pemerintah di China dan Korea kembali mendesak Jepang untuk membayar kompensasi langsung kepada korban. Meski negara itu juga sudah dikunci melalui perjajian pampasan perang seperti juga di Indonesia-Cina tahun 1972 dan Korea tahun 1965. Namun tetap untuk Pemerintah Korea Selatan saat ini menuntut kompensasi pekerja paksa menggunakan orang Korea oleh tentara jepang yang bekerja untuk perusahaan Mitsubisih Heavy Industries (MHI) yang lokasi pabriknya berada di Nagoya-di bawah kontrol Militer Jepang.

Melalui petisi yang ditanda tangani lebih dari 130.000 warga Korea Selatan dan 100 anggota Majelis Nasional menuntut bahwa MHI meminta maaf kepada perempuan dan memberi kompensasi hak untuk para korban. Kemudian, mengancam boikot jika perusahaan (MHI) gagal untuk melakukannya. MHI akhirnya bersedia mengumumkan untuk memulai pembicaraan kompensasi untuk sekira 300 orang perempuan korea. 300 orang wanita Korea yang tertipu pada saat itu berusia remaja, bekerja keras tanpa bayaran di pabrik pesawat di Nagoya.
Maret 2007, pemerintah Jepang membuka dokumen rahasia selama enam dekade dengan dengan data memperlihatkan penggajian untuk 175.000 warga Korea yang bekerja paksa untuk perusahaan swasta di Jepang. Catatan termasuk rincian upah $¥ 278,000,000$ (sekitar 3 juta dolar, disesuaikan dengan inflasi atau bunga) terkait wajib kerja paksa militer tidak pernah dibayarkan kepada para korban selama masa kerja. Uang yang tidak dibayarkan tersebut sebenarnya telah ada lama selama masa perang di Bank of Japan (BOJ). Meski Korea Selatan telah melepaskan semua hak atas dana di bawah perjanjian 1965 dengan Jepang, namun para pejabat pemerintahan di Seoul tetap menggunakan data untuk memverifikasi catatan sejarah kerja paksa (Undewood, Williams. 2010).

Sebuah hak banding 2007 mengotorisasi pembayaran jumlah tetap dana untuk wajib militer Korea Selatan dan mantan anggota keluarga berdasarkan besarnya dana keuangan yang ada di BOJ. Sekitar 700.000 warga sipil Korea ditugaskan untuk bekerja untuk perusahaan swasta di Jepang dan sekitar 300.000 dimobilisasi wajib militer militer di luar negeri. Sekitar 40.000 tahanan Cina dan 35.000 tentara sekutu dijadikan buruh paksa di Jepang, sementara jutaan orang dari Asia Barat dan bekerja tanpa bayaran dalam kondisi yang mengerikan di tempat lain di kekaisaran Jepang.

Nishimatsu Oktober lalu mengumpulkan dana 250 juta yen untuk mengompensasi 360 orang Cina yang dipaksa untuk membangun pembangkit listrik tenaga air di Yasuno di Prefektur Hiroshima. Sementar itu, dana sebesar $¥$ 128.000.000 dikumpulkan April lalu untuk mengkompensasi 183 pekerja paksa China yang telah bekerja di Shinanogawa di Niigata Prefektur. Kompensasi tersebut termasuk bentuk permintaan maaf dan pembayaran kepada korban atau ahli warisnya, karena sebagian besar pekerja telah meninggal.

Perjanjian April tahun 2007 pengadilan di Mahkamah Agung Jepang, yang mengumumkan bahwa pernyataan bersama (mengenai perjanjian pasca perang) antara pemerintahan Jepang-Cina pada tahun 1972 ternyata memadamkan hak individu korba pekerja paksa China untuk mengajukan tuntutan hukum atas kerusakan yang terkait dengan perang. Bergema pengadilan yang lebih rendah dalam kasuskasus terkait, bagaimanapun, Pengadilan Tinggi juga menemukan bahwa Perusahaan Nishimatsu di Jepang dan pemerintah Jepang secara bersama mengoperasikan bisnis ilegal karena menerapkan kerja paksa di tempat kerja 
Shinanogawa dan merekomendasikan wajib "bantuan" bagi korban Cina.

Namun, setelah kesepakatan Shinanogawa Nishimatsu selesai pada bulan April, lima penggugat gagal untuk mengumumkan pada konferensi pers di Beijing karena mereka menolak perjanjian dan mempertimbangkan tindakan hukum di Cina. Akhirnya tim pengacra penggugat mulai melakukan negosiasi dengan Nishimatsu atas nama kelompok yang lebih besar yang mengatasnamakan korban Shinanogawa yang tidak turut berpartisipasi dalam proses hukum yang panjang. Kang Jian, seorang pengacara Cina yang memainkan peran penting dalam 13 tuntutan hukum yang berkaitan dengan perang di Asia Pasifik oleh Jepang. Kemudian sangat mendukung lima pelamar, menolak kesepakatan Nishimatsu. Kang mengritik perusahaan karena bermain "kata-kata" dengan menolak untuk menerima tanggung jawab hukum mengenai kerja paksa, bahkan jika Mahkamah Agung di Jepang memutuskan bahwa tidak ada kewajiban dan tidak ada kompensasi yang digambarkan sebagai kerusakan moril dan fisik. Tuduhan mereka dipublikasikan secara luas di media China (Undewood, Williams. 2010).

Jaksa bernama Toru Takahashi Jepang sangat menyesalkan bahwa penggugat Cina akhirnya ditolak dari kasus koloni kerja paksa Nishimatsu. Dia menjelaskan bahwa kelompok pengacara dengan klaim korban perang Cina, yang sejak tahun 1995 telah menyatakan puluhan tuntutan hukum di Jepang atas dasar pro bono, telah secara implisit selalu bekerja atas nama semua korban Shinanogawa karena Pemerinth Jepang tidak mengizinkan class action.

Dalam perjanjian tahun 2010, Nishimatsu mengakui tanggung jawab karena melakukan kerja paksa. Kemudian meminta maaf kepada korban dan berkomitmen untuk pembayaran per kapita lebih dari \$ 7.000 - angka yang sedikit lebih tinggi dibandingkan pada tahun 2009 perjanjian perusahaan dengan pekerja dari situs Yasuno. Lebih penting lagi, kompensasi Shinanogawa merupakan program yang dikelola oleh sebuah yayasan dari Cina untuk pertama kalinya. Kelima penggugat yang menolak kesepakatan itu, sebagian besar keluarga korban yang meninggal selama persidangan, serta didukung oleh donor swasta di Cina.

Takahashi mengatakan pengacara kelompoknya berencana untuk memulai kunjungan sekitar 20 perusahaan Jepang lainnya yang melakukan kerja paksa, mencari tandatanda efek yang dilakukan oleh Nishimatsu. Beberapa perusahaan swasta telah menyatakan minatnya untuk penyelesaian kerja paksa tersebut. Menurut Takahashi, sementara yang lain tetap bersikeras bahwa semua masalah yang berhubungan dengan perang musti diselesaikan. Tidak hanya menikmati keuntungan selama beroperasi di masa perang, juga harus memberikan kompensasi tenaga kerja Cina yang tidak pernah dibayarkan selama perang. Mitsubishi kini sasaran utama pengacara dan kelompok masyarakat di Cina dan Jepang sebagai perusahaan pertambangan global telah menyatakan bersedia untuk menyelesaikan klaim kerja paksa Cina dengan syarat bahwa pemerintah Jepang berpartisipasi dalam proses penyelesaian kerja sama tersebut.

Tuntutan kompensasi dan permintaan maaf aktif dilakukan oleh kelompok-kelompok kemanusiaan di Cina, Korea Selatan, dan kelompok kemanusiaan Jepang itu yang sebenarnya menunjukan kepedulian terhadap isu ini. Meski perjuangan sampai saat ini pemerintah Jepang belum mengakui kesalahan karena kerja paksa tersebut. Pengakuan baru dilakukan beberapa perusahaan (pihak swasta), karena sampai saat ini pemerintah Jepang belum mau mengakui dan memberi kompensasi terhadap korbannya di Cina dan Korea umumnya di kawasan Asia Pasifik.

Efek gerakan Internasional tersebut membuat perusahaan seperti MHI dan Nishimatsu-yang terlibat dalam pengerahan tenaga kerja paksa ini-mendapat tekanan dunia Internasional. Karena jika tidak melakukan pembicaraan dengan para korban pekerja paksa, usaha mereka akan diboikot di luar Jepang. Pihak-pihak yang peduli tetap menggalang dukungan agar masalah tersebut dapat segera diselesaikan secara menyeluruh. Terutama bagi korban (ahli warisnya) dan menuntut pernyataan bersalah secara resmi oleh pemerintah Jepang. Pemerintah bersama kekuatan masyarakat sipil bahu membahu untuk penyeesaian isu ini secara tuntas.

Sayang usaha gerakan ini tidak terjadi di Indonesia karena kurangnya kepedulian dan kurang tahunya mengenai perkembangan isu tersebut. Kemudian tidak terbangunya gerakan dari level masyarakat golongan ke bawah yang merupakan mayoritas korban kerja paksa (romusha). Apalagi pemerintah tidak konsen dengan isu ini, begitu juga kelompok masyarakat sipil tidak memiliki kemauan dan energi untuk mengurus hal ini. Gerakan kemanusiaan ini memang cenderung muncul di negara maju, karena persoalan kemiskinan, pekerjaan, dan ketimpangan sosial relatif dapat tertangani. Isu kemanusiaan ini menjadi sesuatu yang sulit diperjuangkan jika tidak adanya tekad 
dan komitmen bersama untuk maju bahu membahu dalam menyelesaikannya.

\section{KESIMPULAN}

Periode Invasi Jepang di Indonesia merupakan peristiwa kelam yang tidak dapat dilupakan begitu saja oleh generasi yang mengalami. Kehadirannya banyak membawa perubahan sekaligus kerusakan. Perubahan dari bangsa yang inferior namun menjadi relatif bangkit karena adanya momentum ini. Mengalami kerusakan karena dieksploitasi dan menjadi korban peperangan di kawasan Asia Pasifik. Meski hanya sepenggal cerita dari perjalanan reflektif ini, mampu melihat sisi kemanusiaan. Dampak perang yang terjadi pasti bersifat destruktif dan merugikan semua pihak.

Melihat sisi sejarah romusha membuat merasakan pedihnya perjuangan bangsa Indonesia untuk mendapatkan hak hidup. Mobilisasi manusia oleh Militer Jepang untuk tetap mengobarkan perang melalui pelbagai cara. Ini memperlihatkan bagaimana wilayah Indonesia menjadi posisi penting dan benteng terakhir pertahanan Militer Jepang di kawasan Asia Pasifik. Melalui slogan tipu daya kampanye politik yang akan memajukan Asia Raya yang berkeadilan dan sensib seperjuangan. Mobilisasi untuk pekerja paksa tetap dilakukan dengan dalih itu. Massa dikerahkan tanpa kenal usia adalah tindakan kejam. Seperti yang terjadi pada kasus Boyolali, masyarakat dilibatkan untuk membuat wilayah pertahanan, tanpa tahu yang mereka lakukan. Belum lagi kondisi mengenaskan para pekerja yang tidak kenal lelah bekerja mewujudkan hal itu. Mengorbankan segenap harta, jiwa, dan martabat bangsa.

Sebagai sejarah kelam tentunya persoalan ini mesti diselesaikan secara berkeadilan bagi semua pihak yang terlibat. Mungkin ketika menuliskan kata-kata ini kondisi ex-romusha sudah tua rentan, menatap kepedihan mendalam akibat sakit yang menderanya tanpa ada tempat mengadu. Kepedihan yang akhirnya hanya terpendam dalam alam pikiran, tanpa ada penyelesaian yang jelas.

Bagi konteks di Indonesia hubungan ekonomi-politik yang harmonis dengan pemerintah Jepang dan perusahannya membuat matinya tuntutan penyelesaian kasus tersebut. Gerakan untuk isu tersebut menjadi mandek, karena pengaruh juga terhadap dominasi modal Jepang di Indonesia. Itulah yang mengunci secara politik konteks kekinian bagi pengakuan kembali, permintaan maaf, dan persoalan ganti rugi terkait korban kerja paksa jaman Jepang.
Hasil riset banyak terkumpul dalam perspektif yang berbeda, namun penderitaan romusah kian tergerus seiring dengan waktu. Sebagai sebuah tulisan kiranya bukan sesuat yang provokatif jika masalah romusha Indonesia diangkat dan diperjuangkan kembali dalam sebuah forum Interasional. Karena korban pengerahan tenaga kerja begitu besar, 17.000 orang-yang terdata oleh YLBHI - berasal dari Indonesia.

Isu ini tidak mengalami perkembangan karena ada aspek keadilan dan kemanusiaan yang hilang dalam dukungan gerakan kemanusiaan untuk romusha, antara lain: pertama tidak didukungnya sedari awal gerakan ini secara politik oleh pemerintah karena faktor hubungan ekonomi dan politik yang baik dengan Jepang (sampai saat ini juga), sehingga tuntutan yang diajukan oleh YLBHI ketika konfrensi Oktober 1993 di Jepang dianggap angin lalu. Kedua, tidak ada lagi gerakan di antara organisasi non-pemerintah ( $\mathrm{NgO})$ misalnya, YLBHI atau gerakan kemanusian lain yang menyerukan masalah ini di tingkatan nasional apalagi lagi internasional.

Lalu yang Ketiga, terlampau tunduknya Indonesia dengan Perjanjian Pampasan Perang 1958, yang sebenarnya tidak menyentuh penanganan hak korban secara langsung. Sehingga, apa lacur data 17.000 jiwa $e x$ romusha tengelam dan hilang tidak dimanfaatkan dengan baik di tingkat lokal, apatah lagi di kacah internasional. Isu penyelesaian oleh tanggung jawab invasi militer Jepang di Indonesia terkait romusha kian terkubur seiring meninggalnya para korban. Hasil-hasil riset mustinya dapat mengarah pada langkah tindakan praksis demi tuntasnya penyelesaian kasus berlandaskan prinsip-prinsip keadilan.

\section{DAFTAR PUSTAKA}

Boomgaard, Peter. (2004). Anak Jajahan Belanda: Sejarah Sosial dan Ekonomi Jawa $1795-1880$

Herkusumo, A. Prasedyawati. (1982). Chou Sangi-In: Dewan Pertimbangan Pusat Pada Masa Pendudukan Jepang. Jakarta: P.T. Rosda Jaya Putra.

Ricklefes, M.C. (2005). Sejarah Indonesia Moderen (terj.). Yogjakarta: UGM Press.

Kurasawa, Aiko. (1993). Mobilisasi dan Kontrol: Studi Tentang Perubahan Sosial Di Pedesaan Jawa 1942-1945. Jakarta: Grasindo.

Kurasawa dan Shiraishi. 1988. (Pendudukan Jepang dan Perubahan Sosial: Penyerahan Padi Secara Paksa dan Pemberontakan 
Petani di Indramayu dalam Pemberontakan Indonesia Pada Masa Pendudukan Jepang). Jakarta: YOI.

Suwarno, PJ. (1999). Romusha DIY. Yogyakarta: Penerbit Universitas Sanata Dharma.

Undewood, Williams. (2010). Wartime labor redress efforts at key juncture Campaigns to compensate South Korean, Chinese victims see progress. Japan Times Online.

Nana Syaodih Sukmadinata. (2011). Metode Penelitian Pendidikan. Bandung: PT Remaja Rosdakarya. 